\title{
The Strategies of Technology Startups Within and Between Business Ecosystems
}

\author{
Taina Tukiainen, Thommie Burström, and Martin Lindell
}

\author{
"Strategy is a style of thinking, a conscious and deliberate") \\ process, an intensive implementation system, the science of \\ insuring future success.
}

\author{
Pete Johnson \\ Consultant, author, and speaker
}

\begin{abstract}
Technology startups build strategies in order to survive within the framework of business ecosystems. However, the knowledge required to make such strategies effective is scarce. This article poses the question: "How do small technology startups strategize within and between business ecosystems?" Based on an explorative qualitative study, this article defines and presents a dynamic strategic framework of three strategies employed by technology startups. Some startups choose to act within one defined business ecosystem, most startups use a multi-ecosystem strategy to act between and draw benefits from many business ecosystems, and the rest act as ecosystem creators that challenge the logics of existing ecosystems.
\end{abstract}

\section{Introduction}

There little research and even less evidence to help technology startups strategize in relation to business ecosystems. Therefore, it is important and relevant to study and understand how technology startups behave and develop their strategies and value propositions in a business ecosystem context. We need to broaden our theoretical and practical understanding of business ecosystems and how to support the them. Accordingly, this article takes a business ecosystem perspective and studies strategizing activities among technology startups that have excelled in international listings.

There is a lot of research on how big established business ecosystem leaders act as orchestrators and develop business ecosystem strategies (e.g., Frankort, 2013; Iansiti \& Levien, 2004; Moore, 1993; Peng \& Sanderson, 2014). Indeed, business ecosystem leaders, by dominating technological solutions, have a strong influence on the logic of the whole ecosystem. However, technology startups, who lack both resources and power, may play other important roles than business ecosystem leaders (Brink, 2017; Carree \& Thurik, 2010; Findikoglu \& Watson-Manheim, 2015; Kapoor, 2014; Muegge, 2013; Overholm, 2014; Smith \& Fleck, 1987; Suh \& Sohn, 2015).
Technology startups analyze the technological convergence trends of leading firms (Suh \& Sohn, 2015) and find a role as a niche player, a complementor, or a challenger for the leaders (Iansiti \& Levien, 2004). However, the story is not so simple; there is something missing in our understanding of the strategic behaviour of technology startups (Franco \& Haase, 2013; Sadler-Smith et al., 2001).

Researchers propose that firms can find various routes to success by developing new capabilities (Laamanen \& Wallin, 2009; Zaefarian et al., 2017), undertaking new strategic actions (Rong et al., 2015), and going beyond acting as passive followers. This article draws on research that indicates that small startups can make various choices when strategizing within one or between many ecosystems. They can increase sales by following a single specific ecosystem leader or use a multi-ecosystem strategy in order to create a strong global niche position or even form new ecosystems (Ceccagnoli et al., 2012; Garnsey et al., 2008; Overholm, 2015). This article brings these findings together in proposing the research question: How do small technology startups strategize within and between business ecosystems? 


\section{The Strategies of Technology Startups Within and Between Business Ecosystems}

Taina Tukiainen, Thommie Burström, and Martin Lindell

The structure of the article is as follows. First, we review the relevant literature. Then, we describe the explorative approach used to study the strategic activities of technology startups (Franco \& Haase, 2013; Rong et al., 2015; Suh \& Sohn, 2015). Finally, we describe the results on how technology startups are forming business ecosystem strategies and discuss the implications and limitations.

\section{Literature Review}

\section{Strategic behaviour within and between business} ecosystems

In this article, we define a business ecosystem as a loosely coupled business community and propose that ecosystems are orchestrated by ecosystem leaders in order to create value in collaboration with a community of other actors (Moore, 1993). From the managerial point of view, we often use mobile phone business ecosystems as examples. In these examples, the framework is global and high-tech. However, these examples may or may not work in other industries. In practice, we believe that organizations develop networks that result in competitive advantage, new innovations, or both (Dyer \& Singh, 1998; Gawer, 2014; Sharma \& Henriques, 2005). However, this belief is not sufficiently supported by existing theories. The scope of this article and literature review includes technology startups from the perspectives of business ecosystem leadership, networking, and innovation (Müller-Seitz \& Sydow, 2012). The literature review and resulting research questions are summarized in Table 1.

Taking a leadership role requires resources over long periods of time, whereas taking a follower position requires choosing which leader to follow and how to defend a niche position (Adner, 2006). Niche players can leverage complementary resources from other actors in the ecosystem in order to develop their own special competencies (Iansiti \& Levien, 2004; Maine et al., 2012).

Such leverage demands a relationship view, where firms learn to manage various degrees of close or distant relationships with other actors (Gulati \& Kletter, 2005). For example, small software firms can increase sales by following a specific ecosystem leader (Ceccagnoli et al., 2012), by using a multi-ecosystem strategy (Garnsey et al., 2008), or even by creating ecosystems of their own (Heikkilä \& Kuivaniemi, 2012; Overholm, 2015). Based on the above, our first research question arises:

\author{
RQ1. What strategies can technology startups use \\ to act within and between ecosystems?
}

\section{Business ecosystem leadership}

Ecosystem leadership, platform utilization, interdependencies, and the rules of the game are complex. Business ecosystems are dynamic constructs with no off-the-shelf strategic solutions for achieving ecosystem orchestration. Ecosystem leaders need to decide on strategic engagement models that define how they will collaborate and compete within and between business ecosystems (Bosch-Sijtsema \& Bosch, 2015). Governance mechanisms work differently in different collaborative arrangements, and orchestration cannot be taken for granted (Frankort, 2013). Thus, our second research question arises:

RQ2. How do small technology startups respond to orchestration attempts, and do all technology startups respond in the same way?

Being a business ecosystem leader is not with the same as being a platform leader. Platforms may play an important role when business ecosystem leaders orchestrate business ecosystems (Rong et al., 2013; Yang \& Jiang, 2006). This article defines a platform as an evolving innovative system made of interdependent pieces (Gawer \& Cusumano, 2002). A platform strategy is as an emerging pattern where technology, applications, and organizations play complementary roles (Gawer, 2009; Rong et al. 2013). Ecosystem leaders use platforms as they address the "needs of large, globally heterogeneous group of end users in a manner that would be prohibitively difficult for the platform core to do alone" (Wareham et al., 2014). The relationship between startups and ecosystem-leading platforms have not been sufficiently researched. From a practice and managerial point of view, understanding of this relationship is essential and important and may have a huge effect on management practice.

Less is known of the strategic behaviour of startups in a relation to ecosystem leaders, especially those who are platform-based. From the complementor point of view, our understanding is that a winning formula is to invest in and create products that match the most viable platform (Moore, 1993) and choose to cooperate with a platform owner with the best conflict-control capabilities. However, such selection is far from obvious, since the context seems to be case dependent (Kenney \& Pon, 2011; Tee \& Gawer, 2009;). As an example, a game developer would create its own internal platform and 


\section{The Strategies of Technology Startups Within and Between Business Ecosystems}

\section{Taina Tukiainen, Thommie Burström, and Martin Lindell}

Table 1. Overview of the literature review and research questions

Established Knowledge of Business Ecosystem Strategies
Business ecosystem leaders are both powerful and resourceful, and their orchestrating strategies are well described.

Knowledge Gaps and Research Questions (RQs) Relating to Technology Startups

Technology startups lack any significant power and resources, and they are in search of sustainable business models.

RQ1. What strategies can technology startups use to act within and between ecosystems?

Little knowledge about how technology startups respond to orchestration attempts in business ecosystem.

RQ2. How do small technology startups respond to orchestration attempts, and do technology startups respond in the same way?

Little knowledge about how technology startups connect to leading platforms in business ecosystems.

RQ3. Can startups utilize different strategies when choosing to connect to ecosystem-leading platforms?

Little knowledge about how startups respond to the rules of the game.

RQ4. Should startups strictly follow the rules of the game, stretch the rules of the game, or create new rules of the game? to behave.

Business ecosystem leaders often create the rules of the game, which dictate how collaborators are expected

Innovation

Business ecosystem leaders are utilizing developed innovation networks to cooperate with multiple stakeholders, including universities and research centres, in order to generate new innovations.

Business ecosystem leaders are managing three types of risks: 1) initiative risks, 2) interdependence risks, and 3) integration risks.
Little knowledge about how technology startups go about creating innovations and what type of innovations they create.

RQ5. How do the innovations that technology startups create (and their types) relate to the specific business ecosystems the startups are in?

Little knowledge about how technology startups manage these risks.

RQ6. How do various strategies used by technology startups cover different levels of risk?

$\begin{array}{ll}\text { Networks } & \text { Business ecosystem leaders are in } \\ \text { control of large and relative stable } \\ \text { complex networks where value is co- } \\ \text { created. }\end{array}$

Little knowledge about network management in technology startups.

RQ7. How are startups dealing with network complexity?

RQ8. What characterizes the change patterns related to various business ecosystem strategies? 


\section{The Strategies of Technology Startups Within and Between Business Ecosystems}

Taina Tukiainen, Thommie Burström, and Martin Lindell

then distribute it using global platforms such as Apple's iOS or Google's Android. This strategy may not be suitable for other businesses. For technology startups, the choice is whether to actively create and utilize their own platforms or more passively choose to connect to one or more leading platforms. Thus, our third research question arises:

RQ3. Can small startups utilize different strategies when choosing to connect to ecosystem-leading platforms?

Ecosystem leaders may also try to manage interdependencies by creating and applying the rules of the game, which are necessity for many ecosystems (Jansen \& Cusumano, 2013) and implement the standardized interfaces such as application domains with specific requirements or offer products and complementary services to meet the specific requirements (Mazhelis et al., 2012). As examples, certain software applications are used throughout and across various forms of industries, as in the case of data security, where the software crosses borders. Thus, our fourth research question arises:

RQ4. Should startups strictly follow the rules of the game, stretch the rules of the game, or create new rules of the game (Schumpeter, 1942)?

\section{Innovation in business ecosystems}

The relationship between business ecosystems and innovation is important since new business ecosystems are shaped around novel technologies (Kim et al., 2010). Business ecosystem leaders should orchestrate an innovation infrastructure (Isckia, 2009; Iver \& Davenport, 2008), where novel technologies can form a base for business ecosystem formation (Mazhelis et al., 2012; Rohrbeck et al., 2009). Technology startups can act as niche players and create collaborations within these technological infrastructures (Findikoglu \& WatsonManheim, 2015; Iansiti \& Levien, 2004). Less is known of the options for strategic approaches that technology startups may have in collaborative environments.

Innovations are traditionally described as either incremental or radical. Technology leadership is based on breakthrough innovation (Adner \& Kapoor, 2010; Bessant $\&$ Tidd, 2007). And, between incremental and radical, there is modular innovation (Henderson \& Clark, 1990). An example of a modular innovation is when analogue telephones were replaced by digital phones. The core concept changed, but the linkages between the core design and components stayed the same. Tech- nology startups acting as complementors engage in creating a wide range of innovations, but most are concerned with incremental innovations (Fransman, 2007; Kapoor, 2014). Startups acting as suppliers to business ecosystem leaders face very different innovation challenges: some startups face significant technological challenges, while others do not need to innovate at all (Adner \& Kapoor, 2010). And, some startups focus on component innovation challenges, since components are easier to manage. Thus, our fifth research question arises:

RQ5. How do the innovations that technology startups create (and their types) relate to the specific business ecosystems the startups are in?

On a more practical level, there are three relevant types of risk (Li \& Garnsey, 2014; Shepherd et al., 2000; Smith, 2013; Timmons \& Spinelli, 1999): 1) initiative risks, 2) interdependence and coordination risks, and 3) integration risks (Adner, 2006). The managerial and business understanding, reasonably, states that, the more challenging the business model, $\mathrm{R} \& \mathrm{D}$, or IP issues, the higher the risk to the venture. For example, a game producer that chooses to connect to one or two single existing business ecosystem leaders and follows the rules of the game, takes a lower risk than a producer acting to change the whole system. Consequently, it seems that different potential technology startup strategies bring various risks. Thus, our sixth research question arises:

RQ6. How do various strategies used by technology startups cover different levels of risk?

\section{Networks in business ecosystems}

The roles of orchestrators and niche players are very different in nature. As an example, business ecosystem leaders are orchestrating a value network where they collaborate with a community of complementors (Isckia, 2009; Moore, 1993) and create value sharing mechanisms (Zhang \& Liang, 2011). Less is known about how technology startups act in relation to different networks (La Rocca et al., 2013). As studied, networking can improve effectiveness and efficiency (Gnyawali \& Park, 2009; Perrone et al., 2010), and technology startups can achieve business leverage by connecting to a local keystone (Clarysse et al., 2014). Yet, these dynamics are understudied (Adner 2010; Lin \& Zhang, 2005; Miles \& Snow, 1992).

Technology startups in business ecosystems are interconnected through a network of interdependent actors 


\section{The Strategies of Technology Startups Within and Between Business Ecosystems}

Taina Tukiainen, Thommie Burström, and Martin Lindell

(Christensen \& Rosenbloom, 2013; Thomas \& Autio, 2013). However, network complexity may differ between various types of businesses (Fleck, 1979), making it more or less difficult to manage within ecosystems. As an example, a game developer that links to a single business ecosystem leader would manage within a simple dense network where synchronization is easy to achieve. On the other hand, a technology startup that aims to create a global platform such as MySQL would need to create a global complex network, and synchronization would be difficult to achieve. However, the knowledge of how ecosystem leaders act in such network complexity is limited. Thus, our seventh research question arises:

RQ7. How are startups coping with network complexity?

Value creation and sharing is context and business dependent (Lin \& Zhang, 2005; Isckia, 2009), and change patterns would vary depending on the business strategy a company chooses to follow. For example, in high-tech industries, such as the microchip industry, an ecosystem leader may maintain bargaining power through the control of key elements of value (Adner et al., 2013; Moore, 1993) and business would be relatively stable. If the network is emerging, it is difficult to keep control of any key elements, and that suggests an emerging and novel value-creation pattern. Thus, our eighth research question arises:

RQ8. What characterizes the change patterns related to various business ecosystem strategies?

\section{Research Methods}

Previous business ecosystem studies have focused on the strategic behaviour of powerful and resourceful business ecosystem leaders. In this study, we focus on technology startups, the entrants of business ecosystems.

\section{Data collection and data sources}

We studied 43 small Finnish technology companies that have excelled in the following international listings: Deloitte (2012), Wired (2012), and RedHerring (2013). Our interest is to study how these startups are acting in relation to ecosystem leaders. We decided to explore what kind of relationships these startups have to the ecosystem leader, whether or not they connect to ecosystem leaders, whether they connect to multiple ecosystems or just one, whether they utilize a platform of their own, and how they view opportunities to manoeuvre within and between ecosystems?
These small technology startups were all founded between 2002-2007 and have 11-50 employees. Semistructured interviews and available reports were used for data collection. Two interviews were conducted in each firm (with the CEO and other executive managers). We conducted 86 interviews based on semistructured questions. Each interview lasted for about 1.5 hours. Having more than one respondent per firm provided richer and more elaborated data (Eisenhardt \& Graebner, 2007). Interviews were taped and transcribed. The main themes discussed were the company's: a) historical development, critical events, and acquisitions; b) business ideas and business logics; c) business strategies and competences; d) customers and if those customers were local, international, or global; e) networks, partners, and cooperators; f) product and service development and the use of technical platforms; and g) employee recruitment and leadership; and h) entrepreneurship in a small company; and i) profitability. These themes represent critical business areas. The combined information of these themes allowed us to understand the complexity behind the startups' strategic behaviour. The multiple levels of analysis and the breadth and richness of the data we collected allow us to use qualitative research methods (Strauss \& Corbin, 1990; Yin, 1994). A report was developed for each firm, and each respondent had the opportunity to read and correct a draft version before it was finalized.

\section{Development of a coding schema}

In this study, we used established knowledge of business ecosystem leaders as point of reference for studying the behaviour of small technology startups. We created a qualitative coding scheme allowing us to systematically analyze patterns of management practices (Helfat \& Raubitschek, 2000).

First, we analyzed the characteristics of the startups. We found that $88 \%$ of the startups were acting within a business-to-business (B2B) context, $70 \%$ of the startups were classified as software and consultancy startups, and $90 \%$ of those had software business elements. In other words, the sample includes a broad range of different services that relate to software business models that make use of software.

We continued the analytical process by performing a thematic analysis (Braun \& Clark, 2006). We then performed a cross-case analysis and classified them into three groups based on their strategic behaviour and relationships to ecosystem leaders: 1) startups connected to one ecosystem leader, 2) startups connected to two 


\section{The Strategies of Technology Startups Within and Between Business Ecosystems}

\section{Taina Tukiainen, Thommie Burström, and Martin Lindell}

or more ecosystem leaders, and 3) startups that did not connect to any specific ecosystem leader but instead had ambitions for creating leading an ecosystem.

After identifying this grouping, we analyzed the strategic behaviour of these three groups in greater depth. We compared process data with process theory (Orton, 1997). That is, we first studied our data and then compared it to business ecosystem theory. Initially, three solid behaviours were identified through the analytical process: leadership, innovation, and networking, which had a large impact on the success of the technology startups. The analysis next identified key elements that could explain the variation in behaviour between startups in the three different groups: leadership and platform utilization, interdependencies, and rules of the game; innovation and risk; and network complexity, formation, and value.

\section{Preliminary Analysis}

Based on the cross-case analysis, three empirical storylines describing the typical strategic behaviour of technology startups were identified: 1) linking to one ecosystem leader, 2) linking to many ecosystem leaders, and 3) having ambition to create new ecosystems. These classifications were determined by three researchers and were validated by the participating firms. Results and typical quotations are summarized in Table 2. Also, Boxes 1 to 3 provide overviews of individual companies following each type of strategy.

\section{Connecting to one ecosystem leader}

One group of startups in the study were communicating and interacting within the boundaries of a specified business ecosystem - more specifically, with one specified platform. In this case, the business ecosystem

Box 1. Example case company: Innofactor

Innofactor was founded in 1983, but the present business base was created in 2000. Innofactor is listed at NASDAQ OMX Helsinki. Its turnover in 2015 was 44.5 $\mathrm{M} €$ and it has 427 employees. The CEO descripts the company's development as follows: "We have counted that there have been four stages. The first four years were the start-up phase, a bit like seeking direction. The next four years were about taking over certain niche markets in Finland. The third phase was about getting the number-one spot among the Finnish Microsoft operators. The fourth phase, which is still going on, is about pursuing the number one spot in the Nordic countries."

The goal has been to build up long-lasting customer relationships. The company has operated strictly within the Microsoft ecosystem. In 2011, the company achieved its goal of being the largest firm in the Microsoft ecosystem in Finland and was chosen as the Finnish Microsoft Partner of the Year. The current goal is to be the number one Microsoft partner in the Nordic countries as well.

Innofactor's strategy is to build competitive advantage as the leading provider of Microsoft-based solutions. Innovations are typically of an incremental kind. Innofactor are focusing on solution areas where Microsoft's market position and offering are strongest and which allow Microsoft partners and ecosystem members to grow. Therefore, the risk related to the operation for the company is primarily business risk related to its subsidiaries that carry out business operations. Innofactor plays a central role for Microsoft due to its relationships with customers, but the firm also delivers value-added components for Microsoft business solutions.

The CEO points out that, if Microsoft wants to expand the partnership with someone, they do it with a company with whom they do not have to risk anything. He emphasizes that all partnerships come down to co-operation between people. It requires that you know people: if you want to be a Microsoft partner, you need to know people in Finland and globally.

Observations in relation to research gaps: Microsoft is strongly governing the ecosystem. Innofactor mainly act as a passive adapter and apply Microsoft solutions (RQs 1, 2, 3 4). Innofactor produces to some extent component innovations (RQ5) and mostly carries initiative risks, but perhaps also to some extent integration risk when providing system solutions (RQ6). Innofactor is strongly connected to the Microsoft network (RQ7) and the network can be characterized as esoteric (RQ8). The ecosystem of Microsoft is rather stable and not open for sudden and radical changes (RQ9). 


\section{The Strategies of Technology Startups Within and Between Business Ecosystems}

\section{Taina Tukiainen, Thommie Burström, and Martin Lindell}

boundaries might be slightly changed due to companies' business activities; however, the "rules of the game" stayed the same. Startups followed the rules of the game set by the ecosystem leader. Thus, the business was based on and dependent on the ecosystem leader. From the startup's point of view, their business was regulated by that leader. These startups create value within a certain framework based on the ecosystem leader's technology.

Startups in this group of companies depended on a few tight couplings in the value network. The value creation was simple, with few direct connections. A typical company is an application provider that uses the distribution channels of the ecosystem leader in order to reach customers.
Summing up, companies in this group aligned to a strategy where there was a single ecosystem leader to follow and the rules of the game were defined by that ecosystem leader. The ecosystem leader provided a global platform, while the technology startups utilized platforms of an internal type, as product platforms. The followers were highly dependent on the leader, and business was regulated by that leader. The business and value network did not change much and could be considered to be stable. The network was simple with a few tight connections.

\section{Connecting to multiple ecosystem leaders}

These technology startups are communicating and interacting across business ecosystem boundaries, and they are active within multiple ecosystems. In this way,

Box 2. Example case company: Nitor Creations

Nitor Creations was founded in 2006 by six software experts. The turnover was in $20159 \mathrm{M} €$ and there were 52 employees. Nitor provides architecture design, agile development methods, training, and consulting services. The high level of expertise is emphasized by the CEO: "we founded an expert company for experts, which will serve the customer the best. The most essential thing is the quality of the experts, their passion and ability to do things. Every one of us has at some point been in a reasonably high position and created demanding systems for big customers."

The software solutions are customer co-created with an aim of higher quality at lower cost. Customers are typically large Finnish organizations with their own IT units and with the ability to purchase professional consulting services at the high-end side. The CEO says the following about their customers: "our clientele includes corporations from a variety of fields. All of them have a common goal of concentrating on their core business and on ensuring the proper functioning of their business-critical software solutions with a competent and trusted partner. Our existence is founded on creating genuine added value for customers. We provide an agile and profitable alternative to large and expensive development programs. The competence is based on both on years of reallife experience in customer projects and also through networks. Nitor participates actively in various agile and open sources communities."
Java and Java based programming languages are among Nitor's core competences. The software and system architects have experiences in the most Java Enterprise Edition application servers including Oracle WebLogic, JBoss, IBM WebSphwere, Tomcat, Jetty, and Resin. The most important application framework used is Spring Framework.

Observations in relation to research gaps: Nitor builds tailor-made solutions for customers using a wide range of technologies supplied by many different ecosystem leaders (RQs 1,3 ). Thus, Nitor is not dependent on orchestrating attempts performed by any specific ecosystem leader (RQ2). When building tailor-made solutions for customers, Nitor stretch the rules of the game (RQ4). Nitor is mainly an applier of existing technologies, with focus in architecture building and solutions (RQ5). Nitor has a focus on project management and is open for all three types of risks: initiative risk, interdependence risk, and integration risk (RQ6). When building architecture, Nitor experts are utilizing personal networks (RQ7). The network needed for a project is often complemented with some new required contacts. The network is esoteric (RQ8). The changes in the networks depend on the experts of Nitor and their contacts to agile and open source communities. These contacts are exoteric and competence developing (RQ9). 


\section{The Strategies of Technology Startups Within and Between Business Ecosystems}

Taina Tukiainen, Thommie Burström, and Martin Lindell

they were creating connectivity across ecosystem boundaries, but these boundaries were not being changed. From the platform strategy point of view, there were multiple platforms to follow. The Managing Director in one of the technology startups described why they decided to act across ecosystem boundaries:

\begin{abstract}
"In this strategic option, there was not one specific ecosystem leader that regulated the business. On the contrary, there were multiple platforms to follow, the 'rules of the game' were stretched, and leader dependence was concerted. For the group of startups following this strategy, the business model was adaptive and modular. The technologies adapted were typically known and not new to the industry."
\end{abstract}

For startups following this strategy, one network implication is that the number of loose couplings increased, and so did the complexity of the company's networks. There were multiple networks to be connected and network density and complexity was moderate. Due to the dynamics of the business model, the value network was changing all the time. A typical company using this strategy would be a system supplier or application provider that connects to various industries; therefore, the innovations are typically modular and need to be reconfigured to various environments. The companies learn from various ecosystems and they test the rules of the game, but they do not change the rules of the game.

As a summary, applying this multiple ecosystem strategy means that there are multiple ecosystems and platforms to follow. The ecosystem leader provided a global platform, while the small startups utilized platforms of an internal type, as product platforms. Some were very well developed, while others lacked significantly in maturity. The ecosystem leader dependence was concerted and the rules of the game were stretched. The innovation was modular. The business and value network are multiple, larger, and changeable compared with the one-ecosystem strategy.

\section{Creating new ecosystems}

In the last strategic option, the "rules of the game" are challenged. This type of challenge opens up avenues for new global ecosystem leaders or new platform "wannabes". These wannabes create new rules of the game by trying to orchestrate the new evolving business ecosystems. Startups are trying to span previous business boundaries, thereby putting traditional business boundaries into flux. As these startups typically performed global business, the network became complex with multiple, loose network connections, and the value network found an emerging character. Previous "rules of the game" were therefore severely challenged and re-created. Radical new technology was introduced or business was established in a significantly new way. As a consequence of choosing a radical pathway for conducting business, the risk level was substantially high. A typical company using this strategic option would be a company introducing a new way of doing business, like Uber developing its car-sharing model or Apple's changing the music business by introducing the iPod, or with Apple's new smart e-health solutions, which were launched when the company was still just a technology venture and changed the whole or part of the health industry value logic.

As a summary, if a technology startup were to apply this strategy, it could be seen as a challenger and a new global ecosystem leader wannabe. Typically, these wannabes are aiming to create global new platforms and dictate new rules of the game, thus orchestrating other players. These startups have well developed platform strategies. Radical innovations create opportunities for new ecosystems or ecosystem leader wannabes. With this strategy, the networking requires a lot of multiple, loose connections, it is complex, and new value networks emerge.

Thus, in order to survive in business ecosystems, the technology startups in this study chose to follow one of three strategies. The important elements of each of these strategies are summarized in Table 2, which includes illustrative quotations from the interviews.

\section{Further Results and Discussion}

The preliminary analysis identified three categories of business ecosystem: 1) single-ecosystem, 2) multi-ecosystem, and 3) ecosystem-creation. Among the 43 technology startups in the study, the clear majority $(83 \%, 36$ startups), with less than $10 \%$ following either a singleecosystem strategy $(7.5 \%$, 3 startups) or an ecosystemcreation strategy $(9.5 \%$, 4 startups) followed a multiecosystem strategy. Figure 1 shows the distribution of the startups across the three types.

\section{Single-ecosystem strategy}

Findings in this section confirm and extend the theory of technology startups benefitting from connecting to a specific ecosystem leader (Ceccagnoli et al., 2012). In the single ecosystem strategy, the technology startup follows only one ecosystem leader (RQ1). The platform is given and the firm is complementing the ecosystem 


\title{
The Strategies of Technology Startups Within and Between Business Ecosystems
}

\author{
Taina Tukiainen, Thommie Burström, and Martin Lindell
}

Box 3. Example case company: Kiosked

The company was founded in 2010 and had, in 2015, a turnover of $0.6 \mathrm{M} €$ and 36 employees. The CEO said the following about the company's first development: "We started in 2010. We built the company stone by stone. We recruited only top-class processionals from the very beginning. We have had quite an international company culture from early on. We have 25 nationalities here. We are a very internationally networked company."

Kiosked operates globally in North America, Asia Pacific, and the Europe, Middle East, and Africa (EMEA) region. The business idea was to build socalled "Kiosked" advertisements. The value added for customers is that they do not have to leave themedium they are using to act on an advertisement. If they, for instance, see an appealing holiday place or some interesting new clothes, they can make an order directly without leaving the magazine they are reading or the film they are viewing. Only a click on " $\mathrm{K}$ " in the corner is needed in order to connect them to the system and get all information, and also buy the item.

Kiosked is building their own platform where they aim to use open interfaces. The wide toolset should make it possible for just about anyone to utilize the platform. As described by the CEO: "If we can create a good situation for the ecosystem, we can also create a win-win situation for us and also for the end user."

The firm is working with an extensive network of partners as Magento, Get, PayPal, and global solution partners. They have also created a partner program which tends to grow as business go by. All of the partner operation is global.

Observations in relation to research gaps: Kiosked is aiming to build a global ecosystem of its own (RQ1), and this ecosystem creation involves new technologies, new tools, and system development. Kiosked acts as orchestrator of the platform and ecosystem and does not follow any other global leading company (RQ2). Kiosked is an active co-creator who aims to create win-win situations (RQ4). Kiosked's focus is on building a new business model and develops a platform with novel technical solutions (RQ5). Platform competition is global and so is the strategic intention of Kiosked. The Kiosked business model involves all three types of risk: initiative risk, interdependence risk, and integration risk (RQ 6). Kiosked is building its own global network of partners. Networking is based on earlier personal relationships between the partners and the network has an emerging character (RQs 7, 8). Kiosked follows an emerging novel value-creating pattern (RQ9). by their service offering (RQ3). The firm has to be accepted to the ecosystem by the ecosystem leader. The ecosystem leader sets the "rules of the game" and niche startups follow these rules (RQ4). Thus, startups are highly dependent on the ecosystem leader; the environment can be described as regulated (RQ2). The leader makes decisions on system architecture, interfaces, intellectual property, and the nurturing of entrepreneurship (Jacobides et al., 2006). The leader governs the relationship between the external complementors and decides what to do inside the ecosystem and what should be done outside by external startups (Gawer \& Cusumano, 2002). For technology startups, the innovations are incremental and modify the existing systems (RQ5). In terms of risk, a startup follows a single-ecosystem strategy with initiative risk (Adner, 2006). For example, in the case of developing and launching a new game, technology risks are limited since the ecosystem leader provides technology and distribution help (RQ6).
The contacts to the leader are intensive, there are a few significant partners, and the network formation is reminiscent of a simple classic value chain (RQ7). The network can therefore be labelled as esoteric (Fleck, 1979). From the technology startup's point of view, the value network is simple and stable (RQ8).

\section{Multi-ecosystem strategy}

Findings from these startups confirm and extend the theory of a startup benefitting from connecting to multiple ecosystem leaders (Garnsey et al., 2008). These startups cross boundaries and perform activities within two or more ecosystems (RQ1), thus they may utilize multiple platforms (RQ3). A system integrator is usually following this type of strategy. The startup needs to interpret the behaviour of several ecosystem leaders. Both the challenge and the opportunity involve catering to the ecosystems involved. Consequently, there is a great demand for adaptability. 


\section{The Strategies of Technology Startups Within and Between Business Ecosystems} Taina Tukiainen, Thommie Burström, and Martin Lindell

\section{Table 2. Ecosystem strategies of technology startups}

\begin{tabular}{|c|c|c|}
\hline Knowledge Gaps & Single-Ecosystem Strategy & Multiple-Ecosystem Strategy \\
\hline $\begin{array}{l}\text { How to utilize } \\
\text { platforms }\end{array}$ & $\begin{array}{l}\text { "During the years 2007-2008, } \\
\text { we set the objective to be } \\
\text { number one player in the } \\
\text { Microsoft sector in Finland." }\end{array}$ & $\begin{array}{l}\text { "We have had to be ready for the } \\
\text { fact that our customer's business } \\
\text { ecosystems can be anything; } \\
\text { others may be in open source } \\
\text { type solutions, others are in the } \\
\text { Microsoft ecosystem, while } \\
\text { others are in Oracle." }\end{array}$ \\
\hline
\end{tabular}

\begin{tabular}{llll}
\hline $\begin{array}{l}\text { How to manage } \\
\text { business ecosystem } \\
\text { leader dependence }\end{array}$ & $\begin{array}{l}\text { "Follows a relatively strict } \\
\text { protocol created by the } \\
\text { business ecosystem leader." }\end{array}$ & $\begin{array}{l}\text { "Ecosystems vary enormously } \\
\text { and, therefore, we have had to } \\
\text { adapt to it." }\end{array}$ & $\begin{array}{l}\text { "We build an open interface to our } \\
\text { platform. This has also been the } \\
\text { starting point in building our } \\
\text { ecosystem and toolset." }\end{array}$ \\
\hline
\end{tabular}

\begin{tabular}{ll}
\hline $\begin{array}{l}\text { How to manage in } \\
\text { relation to the rules } \\
\text { of the game }\end{array}$ & $\begin{array}{l}\text { "From Microsoft's point of } \\
\text { anything; they go according } \\
\text { their guidelines." }\end{array}$ \\
\hline
\end{tabular}

\begin{tabular}{ll}
\hline How to manage & Main competitors are the other \\
types of innovation & $\begin{array}{l}\text { companies offering traditional } \\
\text { information technology services } \\
\text { and software. }\end{array}$
\end{tabular}

How to manage risk Profitable implementation of
projects requires that planning before submitting a tender is done successfully as regards the

"There are multiple platforms to follow, "the rules of the game" are "The rules of the game are being created as the business grows." stretched."

\section{Ecosystem-Creation Strategy}

"This is a leading platform enabling smart content turning any online content, images, videos, and applications into interactive and virtual storefronts." amount of work and delivery schedule, and also that the deliveries can be made in a cost-effective manner.

The technologies adapted are typically known and are modified in order to serve various customers.

"Our challenge is to manage within all of these ecosystems and to find the focus there."
The technology is new and the business enabling role of technology has to be invented.
The value-creation network is characterized by simplicity and few direct connections.
How to manage network complexity
As demanding software solutions are today more and more often multivendor environments, independence is further emphasized
A typical company using this strategic option would be a company introducing a new way of doing business.

\begin{tabular}{ll}
\hline How to manage & $\begin{array}{l}\text { Startups in this cluster of } \\
\text { companies typically also } \\
\text { depend on a few tight couplings } \\
\text { in the value network. }\end{array}$
\end{tabular}

in the value network.
We are a horizontal actor; we strive with many extravagant ways to cover the entire value chain, from content production, editing, publishing, and maintenance.
"We have had quite an international company culture: we have 25 nationalities here. We are a very internationally networked company.”

\section{"How do we build international organizations? The simple starting point is that good people bring good people with them. When you know these good people, there are more good people in their network. It is very simple and it works."}

\section{How to manage} value network
"When the technology was working, we started to wonder how to get international clients. We thought; who is the person we want to meet and convince him of us and our product?"
"The value network is changing all the time."
"We are operating in global business. We have technology, development, delivery, and solution partners. We have a very extensive partner network and partner program. This is the way we scale our business quickly, we are not the bottleneck ourselves." 


\section{The Strategies of Technology Startups Within and Between Business Ecosystems}

\section{Taina Tukiainen, Thommie Burström, and Martin Lindell}

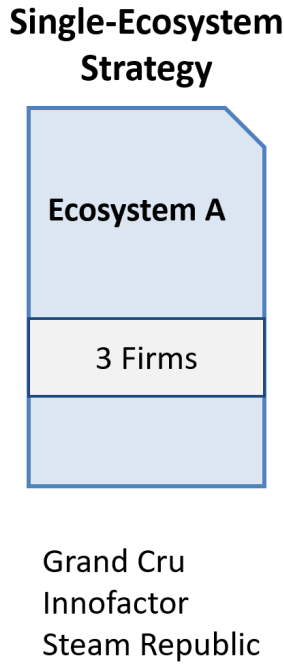

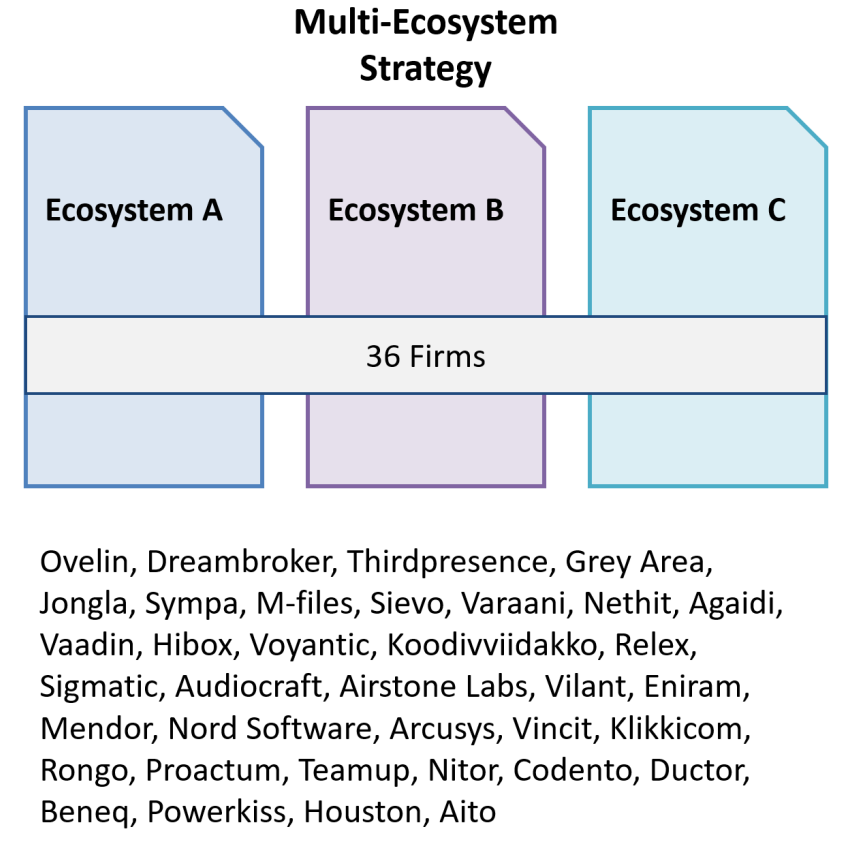

Multi-Ecosystem

Ovelin, Dreambroker, Thirdpresence, Grey Area, Jongla, Sympa, M-files, Sievo, Varaani, Nethit, Agaidi, Beneq, Powerkiss, Houston, Aito

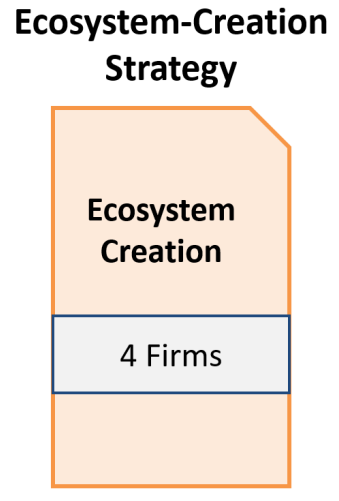

SkySQL

Kiosked Multitouch Conmio

Figure 1. Technology startups in this study, categorized by their business ecosystem strategies

The technology startup learns from the various ecosystems. Startups have to master various technologies, satisfy different types of customers and build their own competence base, and stretch the different types of "rules of the game" (RQ4), but rules are not radically changed (Jansen \& Cusumano, 2013). The environment can therefore be seen as concerted (RQ2) rather than regulated. To survive in these competing environments, the business model and innovation are typically modular (Henderson \& Clark, 1990) (RQ5).

The challenge is to act within all ecosystems and find a focus. The risk level is higher than when following a single-ecosystem strategy. These technology startups face both initiative risk, interdependence risk, and to some extent integration risk (Adner, 2006). Since each business relationship is unique, it follows that each relationship with different ecosystem leaders brings unique initiative, interdependence, and integration risks. For example, a system integration firm faces the challenge of integrating its own knowledge base with various business ecosystem leaders and customers. Since these startups need to manage all three types of risk in multiple ecosystems, the risk pattern becomes more complex and difficult to manage. However, the business ecosystem leaders can give guidelines of how initiative risk, interdependence risk, and integration risk might be managed. Therefore, the risk level can be defined as moderate (RQ6).
There are many network connections and partners in the value network (RQ7). The network is significantly enlarged in comparison with a single platform user (Fleck, 1979; Overholm, 2014). Working with several ecosystem leaders at the same time means that the value network is continuously developing and changing (RQ8). The boundary-crossing startups have to be alert and carefully follow the technological development in the involved ecosystems.

\section{Ecosystem-creation strategy}

Findings from these startup startups confirm and extend the theory of a startups benefitting from acting as ecosystem creators (Overholm, 2015). A technology startup following an ecosystem-creation strategy is a global challenger (RQ1). Typically, this startup challenges previous market boundaries and aims to become a global technology leader. It tries to create its own type of platform, and is therefore, in this study, labelled a "platform wannabe" (RQ3). These platform wannabes are creating "the rules of the game" by attempting to orchestrate other players (RQ4). They want to be new global ecosystem leaders and need to have a vision of the platform architecture (Gawer \& Cusumano, 2002). As ecosystem leaders, they are aiming to decide what to do inside the firm and what to do outside, while also determining the role of external startups in the emerging ecosystem. With this strategy, all stakeholders, complementors, and supplementors are 


\section{The Strategies of Technology Startups Within and Between Business Ecosystems}

\section{Taina Tukiainen, Thommie Burström, and Martin Lindell}

highly needed. The ecosystem-creation startup needs to figure out how create distinct modular system architecture with open interfaces that allow for the protection of intellectual property (Gawer \& Cusumano, 2002; Peng \& Sanderson, 2014).

Previous "rules of the games" are to be challenged as new rules are created with novel technological innovations. The innovations are radical, and new dominant designs are created (Henderson \& Clark, 1990) (RQ5). The radical innovations create opportunities to develop platforms and new ecosystems. At the same time, these startups create destruction in the market and usually disturb existing ways of doing business (Schumpeter, 1942). In terms of risk, boundary-spanning startups not only face all three types of risk (initiative, interdependence, and integration) (Adner, 2006), but they also need to figure out by themselves how to manage the risks. These types of startups are challenging previous ways of doing business; therefore, the risk level is high, and it could be expected that it will take years to reach a positive return on investments (Adner, 2006) (RQ6). The partner network is complex including many tight and loose connections (Jack, 2005) (RQ7). The new platform wannabes work on the border of several industries, and the network formation can be labeled as exoteric (Fleck, 1979). The platform is built step by step, and the value network is in flux and emerging (Adner, 2006; Isckia, 2009) (RQ8).

\section{Summary of results}

The results from the analysis are summarized in Table 3. The first column illustrates research gaps identified in the literature, and the letters and numbers within brackets refer to the questions identified in the review (e.g., RQ2, RQ3). The next columns illustrate the characteristics of each strategy. For example, a technology startup may utilize a single-ecosystem strategy by following a single platform leader, acting in a regulated environment, and following the rules of the game as decided by the ecosystem leader. In reality, the situation is not stable, so the startups also would be able to change from one strategic approach to another.

To answering to the research question about how small technology startups strategize within and between business ecosystems, we have identified and recognized these basic patterns of behaviour. We also found that small startups can have ambitions to create business ecosystems of their own, as described in Table 3. Table 3 indicates that there has to be a fit in the pattern of behaviour between leadership, innovation, and network activities. The small companies select and develop the basic strategy depending on their ambitions and goals.

\section{Conclusions}

The purpose of this article was to understand, discuss, and frame how small technology startups are forming business ecosystem strategies (Brink, 2017; Rong et al., 2015; Zaefarian et al., 2017). This study draws on and integrates previous research findings (Ceccagnoli et al., 2012; Garnsey et al., 2008; Overholm, 2015) and creates a dynamic small-firm ecosystem strategy framework describing three different strategies: a single-ecosystem strategy, a multi-ecosystem strategy, and an ecosystemcreation strategy.

Technology startup strategizing behaviour can differ significantly between startups, and therefore, it can also bring various managerial implications. The traditional approach to business ecosystem research paints a picture of business ecosystem leaders orchestrating their respective ecosystems, where small technology startups are passive followers. This study points out that small technology startups may be masters of their own destinies if they learn to manage the dynamics of related business ecosystems. However, such strategic work demands thorough business ecosystem analysis so that fundamental business interdependencies and value sharing mechanisms are understood in depth. The difference between a single-ecosystem strategy and a multiple-boundary-spanning strategy is substantial; thus, the choice of strategy also places different demands on the dynamic capabilities of the firm.

This article has studied the micro-roles performed in ecosystems (Rong et al., 2015) to better to understand the impacts of various types of startup in ecosystems. In this study, the companies studied were all internationally listed technology startups and were operating in rapidly changing environments, where global business ecosystem leaders such as Intel, Google, Apple, and Microsoft play a dominant role. However, there is a multitude of other businesses, industries, and ecosystems that would be worth examining in future studies. As an example, it would be beneficial to contrast strategies of low-tech startups with the strategies identified in this article. Small startups in such business ecosystems might find a need to apply other business ecosystem strategies. 


\section{The Strategies of Technology Startups Within and Between Business Ecosystems}

Taina Tukiainen, Thommie Burström, and Martin Lindell

Table 3. Dynamics of ecosystem strategies

\begin{tabular}{|c|c|c|c|}
\hline Knowledge Gaps & Single-Ecosystem Strategy & Multi-Ecosystem Strategy & Ecosystem-Creation Strategy \\
\hline $\begin{array}{l}\text { Leader Dependence } \\
\text { (RQ2) }\end{array}$ & Regulated & Concerted & Orchestrated \\
\hline $\begin{array}{l}\text { Platform Utilization } \\
\text { (RQ3) }\end{array}$ & Single-platform follower & Multiple-platform follower & Industry-platform wannabe \\
\hline $\begin{array}{l}\text { Rules of the Game } \\
\text { (RQ4) }\end{array}$ & Follows & Stretches & Creates \\
\hline $\begin{array}{l}\text { Innovation Type } \\
\text { (RQ5) }\end{array}$ & Incremental & Modular / Architectural & Radical \\
\hline $\begin{array}{l}\text { Risk Level } \\
\text { (RQ6) }\end{array}$ & Limited & Moderate & Substantial \\
\hline $\begin{array}{l}\text { Network Complexity } \\
\text { (RQ7) }\end{array}$ & Simple & Multi-part & Complex \\
\hline $\begin{array}{l}\text { Network Formation } \\
\text { (RQ8) }\end{array}$ & Esoteric & Enlarged & Exoteric \\
\hline $\begin{array}{l}\text { Value Network Stability } \\
\text { (RQ9) }\end{array}$ & Stable & Changing & Emerging \\
\hline
\end{tabular}




\section{The Strategies of Technology Startups Within and Between Business Ecosystems}

\section{Taina Tukiainen, Thommie Burström, and Martin Lindell}

\section{About the Authors}

Taina Tukiainen is Professor of Corporate Entrepreneurship and Innovation at Aalto University in Finland. She is also a Cabinet Member of the First Vice President of the EU Committee of the Regions. She has worked for over 10 years at Nokia Corporation and over 15 years globally in universities. Her research interests are entrepreneurship, innovation, strategy, and technology management. Her doctoral dissertation is titled The Unexpected Benefits of Internal Corporate Ventures: An Empirical Examination of the Consequences of Investment in Corporate Ventures (2004), and her latest related books are The Finnish Startups in Globally Evolving Ecosystems: Value for Finland (2014) and The Regional Innovation Ecosystems (2016). She has published in Organization Science and MIT Sloan Management Review and has a wide international network.

Thommie Burström is Rettig Capital Assistant Professor of Management and Organisation at Hanken School of Economics in Helsinki, Finland. His academic interests are in projects, entrepreneurship, business ecosystems, and platform management. Thommie has published papers in, for example, the International Journal of Managing Projects in Business.

Martin Lindell is Professor Emeritus in Entrepreneurship and Management at Hanken School of Economics in Helsinki, Finland. His research interests are in entrepreneurship, creativity, innovation, strategy, and leadership. He has published in many international journals including, among others, Leadership Quarterly, Scandinavian Journal of Management, International Strategic Management and Organization, Journal of Small Business Management, and European Management Journal. He has a wide international network and has been an active member in several international research projects.

\section{References}

Adner, R. 2006. Match Your Innovation Strategy to Your Innovation Ecosystem. Harvard Business Review, 84(4): 98-107.

Adner, R., \& Kapoor, R. 2010. Value Creation in Innovative Ecosystems: How the Structure of Technological Interdependence Affects Firm Performance in New Technology Generation. Strategic Management Journal, 31(3): 306-333.

https://doi.org/10.1002/smj.821

Adner, R., Oxley, J. E., \& Silverman, B. S. 2013. Introduction to Collaboration and Competition in Business Ecosystems. In R. Adner, J. E. Oxley, \& B. S. Silverman (Eds.), Collaboration and Competition in Business Ecosystems, Advances in Strategic Management, Volume 30: ix-xvii. Bingley: Emerald Group Publishing Limited.

https://doi.org/10.1108/S0742-3322(2013)0000030003

Braun, V., \& Clarke, V. 2006. Using Thematic Analysis in Psychology. Qualitative Research in Psychology, 3(2): 77-101. https://doi.org/10.1191/1478088706qp063oa

Bessant, J., \& Tidd, J. 2007. Innovation and Entrepreneurship. Hoboken, NJ: John Wiley \& Sons Ltd.

Bosch-Sijtsema, P. M., \& Bosch, J. 2015. Plays Nice with Others? Multiple Ecosystems, Various Roles and Divergent Engagement Models. Technology Analysis \& Strategic Management, 27(8): 960-974.

https://doi.org/10.1080/09537325.2015.1038231

Brink, T. 2017. SME Routes for Innovation Collaboration with Larger Enterprises. Industrial Marketing Management, 64: 122-134. https://doi.org/10.1016/j.indmarman.2017.01.010

Brunswicker, S., \& Vanhaverbeke, W. 2014. Open Innovation in Small and Medium-Sized Enterprises (SMEs): External Knowledge Sourcing Strategies and Internal Organizational Facilitators. Journal of Small Business Management, 53(4): 1241-1263. https://doi.org/10.1111/jsbm.12120

Brush, C. G., Edelman, L. F., \& Manolova, T. 2002. The Impact of Resources on Small Firm Internationalization. Journal of Small Business Strategy, 13(1): 1-17.

Carree, M. A., \& Thurik, A. R. 2010. The Impact of Entrepreneurship on Economic Growth. In Z. J. Acs \& D. B. Audretsch (Eds.), Handbook of Entrepreneurship Reseach. An Interdisciplinary Survey and Introduction: 557-594. New York: Springer.

Ceccagnoli, M., Forman, C., Huang, P., \& Wu, D. J. 2012. Co-Creation of Value in a Platform Ecosystem: The Case of Enterprise Software. MIS Quarterly, 36(1): 263-290.

Chesbrough, H. 2003. Open Innovation: The New Imperative for Creating and Profiting from Technology. Boston, MA: Harvard Business Press.

Christensen, C. M., \& Rosenbloom, R. S. 2013. Explaining the Attacker's Advantage: Technological Paradigms. Organizational Dynamics and the Value Network. Research Policy, 24(2): 233-267. https://doi.org/10.1016/0048-7333(93)00764-K

Clarysse, B., Wright, M., Bruneel, J., \& Mahajan, A. 2014. Creating Value in Ecosystems: Crossing the Chasm between Knowledge and Business Ecosystems. Research Policy, 43(7): 1164-1176. https://doi.org/10.1016/j.respol.2014.04.014 


\section{The Strategies of Technology Startups Within and Between Business Ecosystems}

\section{Taina Tukiainen, Thommie Burström, and Martin Lindell}

Davis, J. P. 2013. The Emergence and Coordination of Synchrony in Organizational Ecosystems. In R. Adner, J. E. Oxley, \& B. S. Silverman (Eds.), Collaboration and Competition in Business Ecosystems, Advances in Strategic Management, Volume 30: 197-237. Bingley: Emerald Group Publishing Limited. https://doi.org/10.1108/S0742-3322(2013)0000030010

Dyer, J. H., \& Singh, H. 1998. The Relational View: Cooperative Strategy and Sources of Interorganizational Competitive Advantage. Academy of Management Review, 23(4): 660-679. https://doi.org/10.2307/259056

Eisenhardt, K. M., \& Graebner, M. E. 2007. Theory Building from Cases: Opportunities and Challenges. Academy of Management Journal, 50(1): 25-32.

https://doi.org/10.5465/AMJ.2007.24160888

Findikoglu, M. N., \& Watson-Manheim, M. B. 2015. Do Small and Medium-Sized IT Firms Form Service Partnerships with Nonlocal IT Firms? An Assessment of Facilitators. Journal of Small Business Management, 53(4): 986-1010.

https://doi.org/10.1111/jsbm.12117

Fleck, L. 1979. Genesis and Development of a Scientific Fact. (transl. F. Bradley \& T.J. Trenn). Chicago: University of Chicago Press.

Franco, M., \& Haase, H. 2015. Interfirm Alliances: A Taxonomy for SMEs. Long Range Planning, 48(3): 168-181. https://doi.org/10.1016/j.lrp.2013.08.007

Frankort, H. T. W. 2013. Open Innovation Norms and Knowledge Transfer in Interim Technology Alliances: Evidence from Information Technology, 1980-1999. In R. Adner, J. E. Oxley, \& B. S. Silverman (Eds.), Collaboration and Competition in Business Ecosystems, Advances in Strategic Management, Volume 30: 239-282. Bingley: Emerald Group Publishing Limited. https://doi.org/10.1108/S0742-3322(2013)0000030011

Fransman, M. 2007. Innovation in the New ICT Ecosystem. Communications Strategies, 68(4): 89-110.

Garnsey, E., Lorenzoni, G., \& Ferriani, S. 2008. Speciation Through Entrepreneurial Spin-off: The Acorn-ARM Story. Research Policy, 37(2): 210-224.

https://doi.org/10.1016/j.respol.2007.11.006

Gawer, A. 2014. Bridging Differing Perspectives on Technological Platforms: Toward an Integrative Framework. Research Policy, 43(7): 1239-1249.

https://doi.org/10.1016/j.respol.2014.03.006

Gawer, A. 2009. Platform Dynamics and Strategies: From Products to Services. In A. Gawer (Ed.), Platforms, Market and Innovation: 45-76. Cheltenham, UK: Edward Edgar Publishing Limited.

Gawer, A., \& Cusumano, M. A. 2002. Platform Leadership: How Intel, Microsoft, and Cisco Drive Industry Innovation. Boston, MA: Harvard Business School Press.

Gnyawali, D. R., \& Park, B. J. R. 2009. Co-opetition and Technological Innovation in Small and Medium-Sized Enterprises: A Multilevel Conceptual Model. Journal of Small Business Management, 47(3): 308-330.

https://doi.org/10.1111/j.1540-627X.2009.00273.x

Gulati, R., \& Kletter, D. 2005. Shrinking Core, Expanding Periphery: The Relational Architecture of High-Performing Organizations. California Management Review, 47(3): 77-104.

https://doi.org/10.2307/41166307
Hackney, R., Burn, J., \& Salazar, A. 2004. Strategies for Value Creation in Electronic Markets: Towards a Framework for Managing Evolutionary Change. The Journal of Strategic Information Systems, 13(2): 91-103.

https://doi.org/10.1016/j.jsis.2004.02.006

Heikkilä, M., \& Kuivaniemi, L. 2012. Ecosystem Under Construction: An Action Research Study on Entrepreneurship in a Business Ecosystem. Technology Innovation Management Review, 2(6): $18-24$.

https://doi.org/10.22215/timreview/564

Helfat, C. E., \& Raubitscheck, R. S. 2000. Product Sequencing: CoEvolution of Knowledge, Capabilities and Products. Strategic Management Journal, 21(10-11): 961-980.

https://doi.org/10.1002/1097-0266(200010/11)21:10/11<961::AIDSMJ132>3.0.CO;2-E

Henderson, R. M., \& Clark, K. B. 1990. Architectural Innovation: The Reconfiguration of Existing Product Technologies and the Failure of Established Firms. Administrative Science Quarterly, 35(1): 9-30. https://doi.org/10.2307/2393549

Iansiti, M., \& Levien, R. 2004. The Keystone Advantage: What the New Dynamics of Business Ecosystems Mean for Strategy, Innovation, and Sustainability. Boston, MA: Harvard Business School Publishing Corporation.

Isckia, T. 2009. Amazon's Evolving Ecosystem: A Cyber-Bookstore and Application Service Provider. Canadian Journal of Administrative Science, 26(4): 332-342. https://doi.org/10.1002/cjas.119

Iyer, B., \& Davenport, T. H. 2008. Reverse Engineering Google's Innovation Machine. Harvard Business Review, 86(4): 58-69.

Jack, S. L. 2005. The Role, Use and Activation of Strong and Weak Network Ties: A Qualitative Analysis. Journal of Management Studies, 42(6): 231-259.

https://doi.org/10.1111/j.1467-6486.2005.00540.x

Jacobides, M. G., Knudsen, T., \& Augier, M. 2006. Benefiting from Innovation: Value Creation, Value Appropriation and the Role of Industry Architectures. Research Policy, 35(8): 1200-1221. https://doi.org/10.1016/j.respol.2006.09.005

Jansen, S., \& Cusumano, M. A. 2013. Defining Software Ecosystem: A Survey of Software Platforms and Business Network Governance. In S. Jansen, M. A. Cusumano, \& S. Brinkkemper (Eds.), Software Ecosystems: Analyzing and Managing Business Networks in the Software Industry: 13-28. Cheltenham, UK: Edward Edgar Publishing Limited. https://doi.org/10.4337/9781781955635.00008

Kapoor, R. 2014. Collaborating with Complementors: What Do Firms Do? In R. Adner, J. E. Oxley, \& B. S. Silverman (Eds.), Collaboration and Competition in Business Ecosystems, Advances in Strategic Management, Volume 30: 3-25. Bingley, UK: Emerald Group Publishing Limited.

https://doi.org/10.1108/S0742-3322(2013)0000030004

Kenney, M., \& Pon, B. 2011. Structuring the Smartphone Industry: Is the Mobile Internet OS Platform the Key? Journal of Industry, Competition and Trade, 11(3): 239-261. https://doi.org/10.1007/s10842-011-0105-6

Kim, H., Lee, J.-N., \& Han, J. 2010. The Role of IT in Business Ecosystems. Communication of the ACM, 53(5): 151-156. https://doi.org/10.1145/1735223.1735260 


\section{The Strategies of Technology Startups Within and Between Business Ecosystems}

\section{Taina Tukiainen, Thommie Burström, and Martin Lindell}

Laamanen, T., \& Wallin, J. 2009. Cognitive Dynamics of Capability Development Paths. Journal of Management Studies, 46(6): 950-981.

https://doi.org/10.1111/j.1467-6486.2009.00823.x

La Rocca, A., Ford, D., \& Snehota, I. 2013. Initial Relationship Development in New Business Ventures. Industrial Marketing Management, 42(7): 1025-1032.

https://doi.org/10.1016/j.indmarman.2013.07.001

Li, J. F., \& Garnsey, E. 2014. Building Joint Value: Ecosystem Support for Global Health Innovations. In R. Adner, J. E. Oxley, \& B. S. Silverman (Eds), Collaboration and Competition in: Business Ecosystems, Advances in Strategic Management, Volume 30: 69-96. Bingley, UK: Emerald Group Publishing Limited.

https://doi/org/10.1108/S0742-3322(2013)0000030006

Lin, C. Y.-Y., \& Zhang, J. 2005. Changing Structures of SME Networks: Lessons from the Publishing Industry in Taiwan. Long Range Planning, 38(2): 145-162.

https://doi.org/10.1016/j.lrp.2005.02.007

Maine, E., Lubik, S., \& Garnsey, E. 2012. Process-Based vs. ProductBased Innovation: Value Creation by Nanotech Ventures. Technovation, 32 (3): 179-192.

https://doi./org/10.1016/j.technovation.2011.10.003

Mazhelis, O., Luoma, E., \& Warma, H. 2012. Defining an Internet-ofThings Ecosystem. In S. Andreev, B. Balandin, \& Y. Koucheryavy (Eds.), Internet of Things, Smart Spaces and Next Generation Networking: 1-14. Berlin: Springer Berlin Heidelberg. https:// doi.org/10.1007/978-3-642-32686-8

Miles, R., \& Snow, C. 1992. Causes of Failure in Network Organization. California Management Review, 34(4): 53-72.

https://doi.org/10.2307/41166703

Moore, J. F. 1993. Predators and Prey: A New Ecology of Competition. Harvard Business Review, 71(3): 75-86.

Muegge, S. 2013. Platforms, Communities, and Business Ecosystems: Lessons Learned about Technology Entrepreneurship in an Interconnected World. Technology Innovation Management Review, 3(2): 5-15.

https://doi.org/10.22215/timreview/655

Müller-Seitz, G., \& Sydow, J. 2012. Maneuvering between Networks to Lead - A Longitudinal Case Study in the Semiconductor Industry. Long Range Planning, 45(2): 105-135. https://doi.org/10.1016/j.lrp.2012.02.001

Orton, J. D. 1997. From Inductive to Iterative Grounded Theory: Zipping the Gap between Process Theory and Process Data. Scandinavian Journal of Management, 13(4): 419-438. https://doi.org/10.1016/S0956-5221(97)00027-4

Overholm, H. 2015. Collectively Created Opportunities in Emerging Ecosystems: The Case of Solar Service Ventures. Technovation, 3940 (May-June): 14-25.

https://doi.org/10.1016/j.technovation.2014.01.008

Peng, Y.-N., \& Sanderson, S. W. 2014. Crossing the Chasm with Beacon Products in the Portable Music Player Industry. Technovation, 34(2): 77-92.

https://doi.org/10.1016/j.technovation.2013.09.009

Perrone, G., Scarpulla, L., \& Cuccia, L. 2010. Developing Business Networking Opportunities for SMEs through Business Ecosystem and ICT. International Journal of Entrepreneurship and Innovation Management, 11(3): 356-366.

https://doi.org/10.1504/IJEIM.2010.031908
Rohrbeck, R., Hölzle, K., \& Gemünden, H. G. 2009. Opening Up for Competitive Advantage: How Deutsche Telekom Creates an Open Innovation Ecosystem. $R \& D$ Management, 39(4): 420-430.

Rong, K., Lin, Y., Shi, Y., \& Yu, J. 2013. Linking Business Ecosystem Lifecycle with Platform Strategy: A Triple View of Technology, Application and Organization. International Journal of Technological Management, 62(1): 75-94. https://doi.org/10.1504/IJTM.2013.053042

Rong, K., Hu, G., Lin, Y., Shi, Y., \& Guo, L. 2015. Understanding Business Ecosystem Using a 6C Framework in Internet-of-ThingsBased Sectors. International Journal of Production Economics, 159: 41-55. https://doi.org/10.1016/j.ijpe.2014.09.003

Sadler-Smith, E., Spicer, D. P., \& Chaston, I. 2001. Learning Orientations and Growth in Smaller Firms. Long Range Planning, 34(2): 139-158. https://doi.org/10.1016/S0024-6301(01)00020-6

Schumpeter, J. A. 1942. Capitalism, Socialism and Democracy. New York: Harper \& Brothers.

Sharma, S., \& Henriques, L. 2005. Stakeholder Influences on Sustainability Practices in the Canadian Forest Product Industry. Strategic Management Journal, 26(2): 159-180. https://doi.org/10.1002/smj.439

Shepherd, D. A., Douglas, E. J., \& Shanley, M. 2000. New Venture Survival: Ignorance, External Shocks and Risk Reduction Strategies. Journal of Business Venturing, 15(5-6): 393-410. https://doi.org/10.1016/S0883-9026(98)00032-9

Smith, D. 2013. Navigating Risk When Entering and Participating in a Business Ecosystem. Technology Innovation Management Review, 3(5): 25-33.

https://doi.org/10.22215/timreview/685

Smith, J. G., \& Fleck, V. 1987. Business Strategies in Small HighTechnology Companies. Long Range Planning, 20(2): 61-68. https://doi.org/10.1016/0024-6301(87)90007-0

Strauss, A. L., \& Corbin, J. M. 1990. Basics of Qualitative Research: Techniques and Procedures for Developing Grounded Theory. Thousand Oaks, CA: Sage Publications.

Suh, J., \& Sohn, S. Y. 2015. Analyzing Technological Convergence Trends in a Business Ecosystem. Industrial Management \& Data Systems, 115(4): 718-739.

https://doi.org/10.1108/IMDS-10-2014-0310

Tee, R., \& Gawer, A. 2009. Industry Architecture as a Determinant of Successful Platform Strategies: A Case Study of the I-Mode Mobile Internet Service. European Management Review, 6(4): 217-232. https://doi.org/10.1057/emr.2009.22

Thomas, L. D. W., \& Autio, E. 2013. Emergent Equifinality: An Empirical Analysis of Ecosystem Creation Processes. Paper presented at the 35th DRUID Celebration Conference, Barcelona, June.

Timmons, J., \& Spinelli, S. 1999. New Venture Creation: Entrepreneurship for the 21st Century. New York: McGrawHill/Irwin.

Wareham, J., Fox, P., Cano, G., \& Li, J. 2014. Technology Ecosystem Governance, Organization Science, 25(4): 1195-2015. https://doi.org/10.1287/orsc.2014.0895 


\section{The Strategies of Technology Startups Within and Between Business Ecosystems}

Taina Tukiainen, Thommie Burström, and Martin Lindell

Zaefarian, G., Thiesbrummel, C., Henneberg, S. C., \& Naudé, P. 2017. Different Recipes for Success in Business Relationships. Industrial Marketing Management, 63: 69-81.

https://doi.org/10.1016/j.indmarman.2016.12.006

Zhang, J., \& Liang, X. J. 2011. Business Ecosystem Strategies of Mobile Network Operators in the 3G Era: The Case of China Mobile. Telecommunications Policy, 35(2): 156-171.

https://doi.org/10.1016/j.telpol.2010.12.009

Yang, C., \& Jiang, S. 2006. Strategies for Technology Platforms. Research-Technology Management, 49(3): 48-57. https://doi.org/10.1080/08956308.2006.11657378

Yin, R. K. 1994. Case Studies Research: Design and Methods. Newbury Park, CA: Sage.

Citation: Tukiainen, T., Burström, T., Lindell, M. 2019.

The Strategies of Technology Startups Within and

(cc) BY

Between Business Ecosystems. Technology Innovation

Management Review, 9(6): 25-41.

http://doi.org/10.22215/timreview/1247

Keywords: startups, strategy, business ecosystems,

entrepreneurship, boundaries 


\section{Academic Affiliations and Funding Acknowledgements}
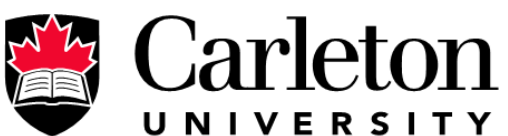

U N I V E R S I T Y

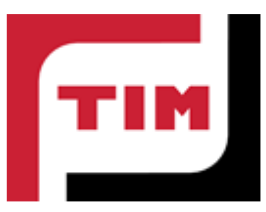

Technology Innovation Management (TIM; timprogram.ca) is an international master's level program at Carleton University in Ottawa, Canada. It leads to a Master of Applied Science (M.A.Sc.) degree, a Master of Engineering (M.Eng.) degree, or a Master of Entrepreneurship (M.Ent.) degree. The objective of this program is to train aspiring entrepreneurs on creating wealth at the early stages of company or opportunity lifecycles.

- The TIM Review is published in association with and receives partial funding from the TIM program. 